\title{
A comparison of greenhouse gas emissions in the residential sector of major Canadian cities
}

Article

Accepted Version

Mohareb, E. A. and Mohareb, A. K. (2014) A comparison of greenhouse gas emissions in the residential sector of major Canadian cities. Canadian Journal of Civil Engineering, 41 (4). pp. 285-293. ISSN 0315-1468 doi:

https://doi.org/10.1139/cjce-2013-0465 Available at https://centaur.reading.ac.uk/44981/

It is advisable to refer to the publisher's version if you intend to cite from the work. See Guidance on citing.

Published version at: http://dx.doi.org/10.1139/cjce-2013-0465

To link to this article DOI: http://dx.doi.org/10.1139/cjce-2013-0465

Publisher: NRC Research Press

All outputs in CentAUR are protected by Intellectual Property Rights law, including copyright law. Copyright and IPR is retained by the creators or other copyright holders. Terms and conditions for use of this material are defined in the End User Agreement.

www.reading.ac.uk/centaur 
Central Archive at the University of Reading

Reading's research outputs online 


\section{A Comparison of Greenhouse Gas Emissions in the Residential}

\section{Sector of Major Canadian Cities}

Eugene A. Mohareb; Department of Civil Engineering, University of Toronto, 35 St. George St., Toronto, ON. eugene.mohareb@alum.utoronto.ca

Adrian K. Mohareb; ClearLead Consulting, 108-245 Fell Ave., North Vancouver, BC.

Abstract: One of the most significant sources of greenhouse gas (GHG) emissions in Canada is the buildings sector, with over $30 \%$ of national energy end-use occurring in buildings. Energy use must be addressed in order to reduce emissions from the buildings sector, as nearly $70 \%$ of all Canada's energy used in the residential sector comes from fossil sources. An analysis of GHG emissions from the existing residential building stock for the year 2010 has been conducted for six Canadian cities with different climates and development histories: Vancouver, Edmonton, Winnipeg, Toronto, Montreal and Halifax. Variation across these cities is seen in their $2010 \mathrm{GHG}$ emissions, due to climate, characteristics of the building stock, and energy conversion technologies, with Halifax having the highest per capita emissions at $5.55 \mathrm{tCO}_{2} \mathrm{e} /$ capita and Montreal having the lowest at $0.32 \mathrm{tCO}_{2} \mathrm{e} /$ capita. The importance of the provincial electricity grid's carbon intensity is emphasized, along with era of construction, occupancy, floor area and climate. Approaches to achieving deep emissions reductions include innovative retrofit financing and city level residential energy conservation by-laws; each region should seek location-appropriate measures to reduce energy demand within its residential housing stock, as well as associated GHG emissions.

Keywords: Climate Change; Greenhouse Gases; Cities; Residential Energy Use; Building Stock

\section{Acknowledgments}

The authors would like to thank Prof. Christopher A. Kennedy for his input related to this work. This work is made possible by funding from the people of Canada through the Natural Sciences and Engineering Research Council. 
Cite as: Mohareb, E.A., \& Mohareb, A.K., 2014. A comparison of greenhouse gas emissions in the residential sector of major Canadian cities. Canadian Journal of Civil Engineering 41 (4), 285293

\section{Introduction}

The motivation to reduce greenhouse gas (GHG) emissions has grown in recent years as scientific evidence of climate change and its potential impacts have become widely recognized (Doran and Zimmerman 2009). It has been suggested that cities contribute over $70 \%$ of global energy-related $\mathrm{CO}_{2}$ emissions (IEA 2008). A trend towards urbanization has been observed both internationally and within Canada, with the percentage of Canadians living within cities has reached 80\% (UN ESA 2013; Statistics Canada 2010). The potential for urbanization in Canada to further increase GHG emissions growth is supported by two observations. First, settlement size demonstrates a super-linear power law relationship with gross domestic product (observed in the US, China and Germany), suggesting higher incomes as urbanization occurs (Bettencourt et al, 2007). Secondly, a positive relationship between income and greenhouse gas emissions has also been suggested, which may lead to higher per capita emissions (Wilson et al, 2013a; Wilson et al, 2013b). As a result, in order to address the challenge presented by climate change, a special focus must be placed on reducing the climate impact of urban infrastructure.

Globally, cities have become early champions for action towards GHG emission reductions (FCM 2013). As a result, many Canadian cities have begun the process of quantifying the sources of these emissions. One of the key contributing sectors is the buildings sector. Given that buildings are long-lived and that deep energy efficiency retrofitting activities have high costs, absolute reductions in GHG emissions from buildings will be difficult to attain (Mohareb and Kennedy 2012). The residential sector also warrants attention since ownership is broadly distributed (as are, consequently, energy decision makers) and this sector contributes a significant proportion to urban emissions. As an example, the City of Toronto has estimated that nearly $25 \%$ of community emissions were attributable to the residential sector (City of Toronto 2007). Similarly, according to the Province of BC's Community Energy and Emissions Inventory, 23\% of the GHG emissions in Metro Vancouver come from the residential sector (Climate Action Secretariat 2013). The IPCC (2007) has suggested that Annex I countries should aim to reduce emission by $80-95 \%$ 
Cite as: Mohareb, E.A., \& Mohareb, A.K., 2014. A comparison of greenhouse gas emissions in the residential sector of major Canadian cities. Canadian Journal of Civil Engineering 41 (4), 285293

by 2050 from a 1990 baseline, and many cities internationally have chosen to adopt this target (including both Toronto and Vancouver).

The goal of this research is to quantify residential GHG emissions for six major Canadian cities by using a bottom-up modeling approach. Quantification of emissions was accomplished using the Pathways to Urban Reductions in Greenhouse gas Emissions, or PURGE, model. To this point, residential emissions have generally not been disaggregated in urban inventories; doing so allows for novel comparisons of GHG emissions from end uses, building types and energy sources from houses in the six cities selected. As well, this study will determine how GHG emissions from the residential sector differ in cities across Canada, and suggest the reasons for these differences. This quantification exercise will highlight the specific challenges facing the residential sector in different Canadian cities in meeting the IPCC's targeted emission reductions and achieving carbon neutrality.

\section{Methodology}

\subsection{Residential Housing Stocks of Six Canadian Cities}

Six major Canadian cities were selected, based on population size, as well as differences in climate, eras of development, energy sources and types of buildings prevalent in their building stock. A summary of key statistics for the Census Metropolitan Areas (CMAs) examined is presented in Table 1.

A number of factors dictate urban housing stock dynamics, such as population growth, regional economic development, immigration policy, geographic constraints and geopolitical dynamics. One example would be the surge in population in the province of Alberta due to oil sands development, with Alberta growing by $10.8 \%$ between 2006 and 2011, compared to the national average of 5.9\% (Statistics Canada 2012; Mansell \& Schlenker 2006). 
Cite as: Mohareb, E.A., \& Mohareb, A.K., 2014. A comparison of greenhouse gas emissions in the residential sector of major Canadian cities. Canadian Journal of Civil Engineering 41 (4), 285293

Table 1: Summary Statistics of Six Canadian Cities (based on CMA's; Statistics Canada, 2011; Degreedays.net)

\begin{tabular}{|c|c|c|c|c|c|c|}
\hline \multirow{2}{*}{$\begin{array}{c}\text { Census } \\
\text { Metropolitan } \\
\text { Area }\end{array}$} & \multirow{2}{*}{$\begin{array}{c}\text { Population } \\
\text { (2011) }\end{array}$} & \multirow{2}{*}{$\begin{array}{c}\text { Population } \\
\text { Density } \\
(2011 \text {; per } \\
\left.\mathrm{km}^{2}\right) \\
\end{array}$} & \multicolumn{3}{|c|}{ Building Stock $(2006)$} & \multirow[b]{2}{*}{$\begin{array}{c}\mathrm{HDD}(\text { Base }= \\
\left.18^{\circ} \mathrm{C}\right)\end{array}$} \\
\hline & & & $\%$ SFA & $\%$ SFD & $\%$ MUR & \\
\hline Vancouver & $2,419,733$ & 803 & $25.4 \%$ & $33.8 \%$ & $40.1 \%$ & 2929 \\
\hline Edmonton & $1,196,342$ & 123 & $15.2 \%$ & $58.6 \%$ & $24.5 \%$ & 5867 \\
\hline Winnipeg & 762,759 & 138 & $8.2 \%$ & $62.9 \%$ & $28.2 \%$ & 5540 \\
\hline Toronto & $5,838,838$ & 945 & $20.7 \%$ & $41.3 \%$ & $37.9 \%$ & 3613 \\
\hline Montreal & $3,908,723$ & 898 & $17.2 \%$ & $32.6 \%$ & $49.7 \%$ & 4042 \\
\hline Halifax & 408,198 & 71 & $14.3 \%$ & $51.0 \%$ & $32.1 \%$ & 4051 \\
\hline
\end{tabular}

SFA = Single Family Attached Units; SFD = Single Family Detached Units; MUR = Multi-Unit Residential; HDD = Heating Degree Days (at International Airport); ${ }^{1}$ Figures do not total $100 \%$ as moveable dwellings are not included

The age distribution of buildings in various cities is another important factor in calculating GHG emissions. Building envelope characteristics are associated with the era of construction, varying due to building codes and owner-initiated retrofitting initiatives over time. Building codes have included more energy-saving measures over time, resulting in lower heating energy demand per unit of floor area (OEE 2012a). As well, other building characteristics also vary over time; some examples include the use of window walls in modern high rise multi-unit residences (due to their low cost, perceived market demand and ease of installation; Kesik 2011) and the increases in single family unit floor area over time (OEE 2012a). Finally, proportions of building type (and unit sizes) have been observed to change over time. Preference in unit types also varies with market conditions, which can impact GHG emissions (single family units have generally had greater gross floor areas than multi-unit residential (MUR) units, though the latter have lower occupancies per unit). For example, while MUR housing has historically been popular in the Montreal CMA, a recent shift towards the construction of single family detached (SFD) units has been observed since the 1990s (see Figure 1 for detailed information on types of units constructed by era for 
Cite as: Mohareb, E.A., \& Mohareb, A.K., 2014. A comparison of greenhouse gas emissions in the residential sector of major Canadian cities. Canadian Journal of Civil Engineering 41 (4), 285293

each of the study cities). Additionally, histograms detailing the 2006 building stock by era of construction are seen in Figure 2.
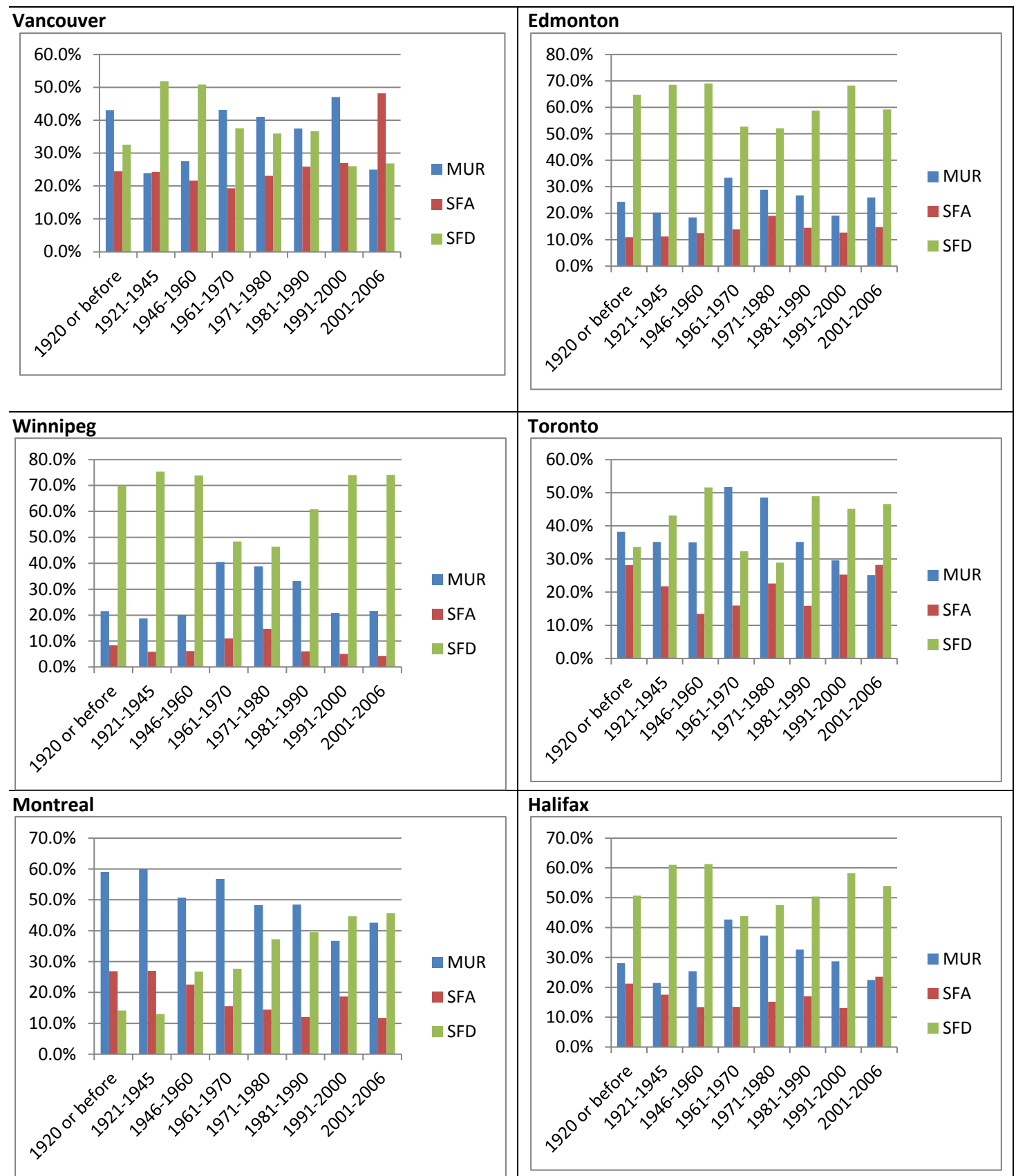

Figure 1: Types of Units Constructed in Various Eras by City, 2006 (Statistics Canada 2006) 
Cite as: Mohareb, E.A., \& Mohareb, A.K., 2014. A comparison of greenhouse gas emissions in the residential sector of major Canadian cities. Canadian Journal of Civil Engineering 41 (4), 285293



Figure 2: Proportions of Housing Stock by Era of Construction (Statistics Canada 2006) Note: Right-Most Bar Covers the Period 5-Year Period Between 2001-2006

For all the cities studied, there is a spike in housing stocks from the period between 1946-1960 relative to previous eras, attributable to immigration and natural population growth during that era (Statistics Canada 2005). However, unique surges and declines in the stock growth rate can be seen when comparing current stocks between cities, due to changing economic conditions. Some examples include the substantial proportion of Edmonton's building stock constructed in the 1970's during its rapid population growth at the time (likely attributable to the OPEC-induced rise in oil prices), and the lower proportion of buildings built in Winnipeg's recent history due to population declines (Mansell \& Schlenker 2006; City of Winnipeg 2007). 
Cite as: Mohareb, E.A., \& Mohareb, A.K., 2014. A comparison of greenhouse gas emissions in the residential sector of major Canadian cities. Canadian Journal of Civil Engineering 41 (4), 285293

\subsection{The PURGE Model}

The PURGE model is a method for quantifying and projecting urban GHG emissions over time from buildings, private transportation, and waste (Mohareb and Kennedy 2012). In this study, the residential building GHG module is applied to quantify emissions from the building stock in 2010 . Modeled data allows for the estimation of GHG emissions attributable to specific eras of construction and types of residence, on a per capita basis; this could not be achieved from data provided by utilities, as information on housing characteristics or occupancy are not publicly available. The PURGE model has been validated through a comparison with recent GHG inventory data from Civic Action (2011); results from building sector energy consumption (natural gas and electricity) using the PURGE model differed from 2008 and 2009 GHG inventories using utility data by less than $10 \%$. The Office of Energy Efficiency's (OEE) energy end-use database (OEE 2012a), microdata from the 2006 census (Statistics Canada 2006) and population growth figures from the 2011 Canadian census are used to quantify GHG from the building technology stock in the CMAs of interest to this study. The most recently available data from all sources were applied if 2010 data were not accessible. Projections of housing stock change between 2006-2010 were applied based on the most recently available census microdata (2006), holding the proportion of dwelling type constructed constant from the most recently available building characteristics data (2001-2006). Additionally, dwelling sizes (i.e. floor area) of new construction are held constant from 2006-2010 as well, based on sizes from the previous census period. Detailed tables of inputs applied to the PURGE model are provided in the "Supplementary Materials" section. Error associated with changes in new building stock characteristics in this period will have a minimal impact, given that the overwhelming majority of citizens ( 95\%) in each city are still housed in buildings constructed before 2006.

The sum of $\mathrm{GHG}$ emissions from buildings $\left(\mathrm{GHG}_{\text {Buildings }}\right)$ in year $t$ are given by Equation 1, summing by era of construction,

$$
G H G_{\text {Buildings }}(t)=\sum_{\text {Type Era }} U(t) \bullet \bar{A} \bullet\left[\sum_{S E} C(t) \bullet E I(t)\right]
$$


where, in year $t, U$ is the total number of units of a given unit type and era, $\bar{A}$ is the average floor space of the building type from a given era $\left(\mathrm{m}^{2}\right), S E$ is the secondary energy type for a, $C$ is the consumption of a secondary energy type for a given building type and era (either electrical or fossil energy; $\left.\mathrm{GJ} / \mathrm{m}^{2}\right)$ and $\mathrm{El}$ is emissions intensity of the energy source used $\left(\mathrm{CO}_{2} \mathrm{e} / \mathrm{m}^{2}\right)$. A variation on Equation 1 is applied for calculating domestic hot water demand ( $\left(\mathrm{HHG}_{\mathrm{DHW}}\right)$ (Equation 2),

[2]

$$
G H G_{D H W}(t)=\sum_{T y p e} U(t) \bullet O \bullet\left[\sum_{S E} C(t) \bullet E I(t)\right]
$$

where $O$ (capital letter "O") is the average occupancy per unit observed in a given type of residence (single family attached, single family detached and multi-unit residential, or SFA, SFD and MUR, respectively) for a specific CMA (Statistics Canada 2006). The number of new units required in a year $t$ of a specific unit type is described in Equation 3.

[3]

$$
U_{\text {Type }, \text { New }}(t)=\frac{P(t)}{O} \bullet f_{\text {Type }}-\sum_{\text {Era }} U_{\text {Type }, \text { Era }}(t)
$$

where for a given housing type (single family or apartment) constructed in a given year, $U_{\text {Type New }}$ is the number of new units, $U_{\text {Type,Era }}$ is the number of old units from a specific era, and $f_{\text {Type }}$ is the fraction of the urban population (P) living in a dwelling type. Equation 4 describes the number of units remaining in year $t$ from a given era of construction.

$$
U_{\text {Type,Era }}(t)=U_{\text {Type,Era }}(t-1)-D_{\text {Type }}(t)
$$

where $D$ is the number of units demolished. Units demolished of a given type ( $\left.D_{\text {type,era }}\right)$ in year $t$ is a function of building age and the rate of demolition of buildings constructed in a specific era and is assumed to be linear in the PURGE model (Equation 5).

[5] $D_{\text {type }}(t)=A \bullet \varphi$ 
Cite as: Mohareb, E.A., \& Mohareb, A.K., 2014. A comparison of greenhouse gas emissions in the residential sector of major Canadian cities. Canadian Journal of Civil Engineering 41 (4), 285293

where $A$ is the building age in years and $\varphi$ is the rate of demolition (units / yr). A linear regression of housing stock decline obtained from OEE (2012a) is the basis of the calculation of $\varphi$. In the 2011 Census, building stock data that had been previously collected from the long-form census was moved to the voluntary National Household Survey. As a result, 2006 Census data are used for quantifying building stocks in the relevant CMAs. Urban building stock data from different eras and occupancy by type for the different cities studied are taken from Statistics Canada census data on total occupied dwellings (Statistics Canada 2006). Building stock change, building floor area, and rate of demolition are acquired or calculated from OEE's energy end use database (2012a), scaled from provincial data, where necessary, using census data (Statistics Canada 2012; Statistics Canada 2006). Building heating energy consumption (disaggregated by energy source) is applied as described by type and era of construction in OEE (2012a), which uses the Residential End-Use Model (National Resources Canada 2012). Assumptions for annual fuel utilization efficiency of normal-, medium- and high-efficiency oil and natural gas furnaces are $60 \%, 75 \%$ and $85 \%$, and $62 \%, 78 \%$ and $90 \%$, respectively (based on definitions provided OEE 2012a).

Electricity consumption per square metre of residential floor area related to lighting, space cooling and appliances (refrigerators, clothes washers/dryers, dish washers, freezers, electric ranges) is assumed to vary by province, but uniform across building type and era of construction. Appliance electricity consumption per province is calculated based on OEE provincial estimates of appliance stocks, weighted national average of unit energy consumption (UEC) per appliance and average appliance ages (OEE 2012a; OEE 2012b; OEE 2010). This was calculated in accordance with Equation 6.

[6] $\overline{U E C}=\sum_{\text {era }} f_{\text {app }} \times \overline{U E C}_{\text {era }}$

where $\overline{U E C}$ is the weighted national average electricity consumption of a given appliance, with $f_{\text {appera }}$ and $\overline{U E C}_{\text {era }}$ being the national fraction of that appliance belonging to a given era and the average UEC over the same era, respectively. This is presented in Table 2. 
Cite as: Mohareb, E.A., \& Mohareb, A.K., 2014. A comparison of greenhouse gas emissions in the residential sector of major Canadian cities. Canadian Journal of Civil Engineering 41 (4), 285293

Table 2: Non-Heating Electricity Requirements for Residences from Different Provinces (PJ) (Calculated from OEE 2012a, OEE 2012b and OEE 2010)

\begin{tabular}{crrrrrr}
\hline Province & AB & BC & MB & NS & ON & QC \\
\hline Lighting & 7.5 & 9.2 & 2.7 & 1.4 & 14.3 & 15.2 \\
Cooling & 0.2 & 0.8 & 1.6 & 0.2 & 17.7 & 5.5 \\
Appliances & 17.46 & 20.13 & 5.43 & 4.45 & 54.34 & 38.81 \\
\hline Average Demand & 36 & 31 & 47 & 30 & 34 & 42 \\
$\left(\mathrm{kWh} / \mathrm{m}^{2}\right)$ & & & & & & \\
\hline
\end{tabular}

Electricity grid emissions factors are taken from the 1990-2010 Greenhouse Gas National Inventory Report (Environment Canada 2012; Figure 3). As observed by Kikuchi et al (2009), grid emissions factors greatly impact GHG emissions from retrofit decisions and, as a result, policy related to emissions reductions; the replacement of natural gas furnaces with geoexchange heating can increase household GHG emissions in areas with carbon-intensive electricity grids. As is seen from Figure 3, Alberta and Nova Scotia face significant hurdles in reaching carbon neutrality in the residential sector based on their electricity grid alone, which are both heavily reliant on coal and other fossil sources of energy. Nova Scotia currently has a strategy for a $50 \%$ reduction in the share of coal in their electricity grid by (based on 2010 consumption figures); this will be accomplished by increasing the share of renewable electricity generation to $40 \%$ (Nova Scotia Department of Energy 2010). 
Cite as: Mohareb, E.A., \& Mohareb, A.K., 2014. A comparison of greenhouse gas emissions in the residential sector of major Canadian cities. Canadian Journal of Civil Engineering 41 (4), 285293

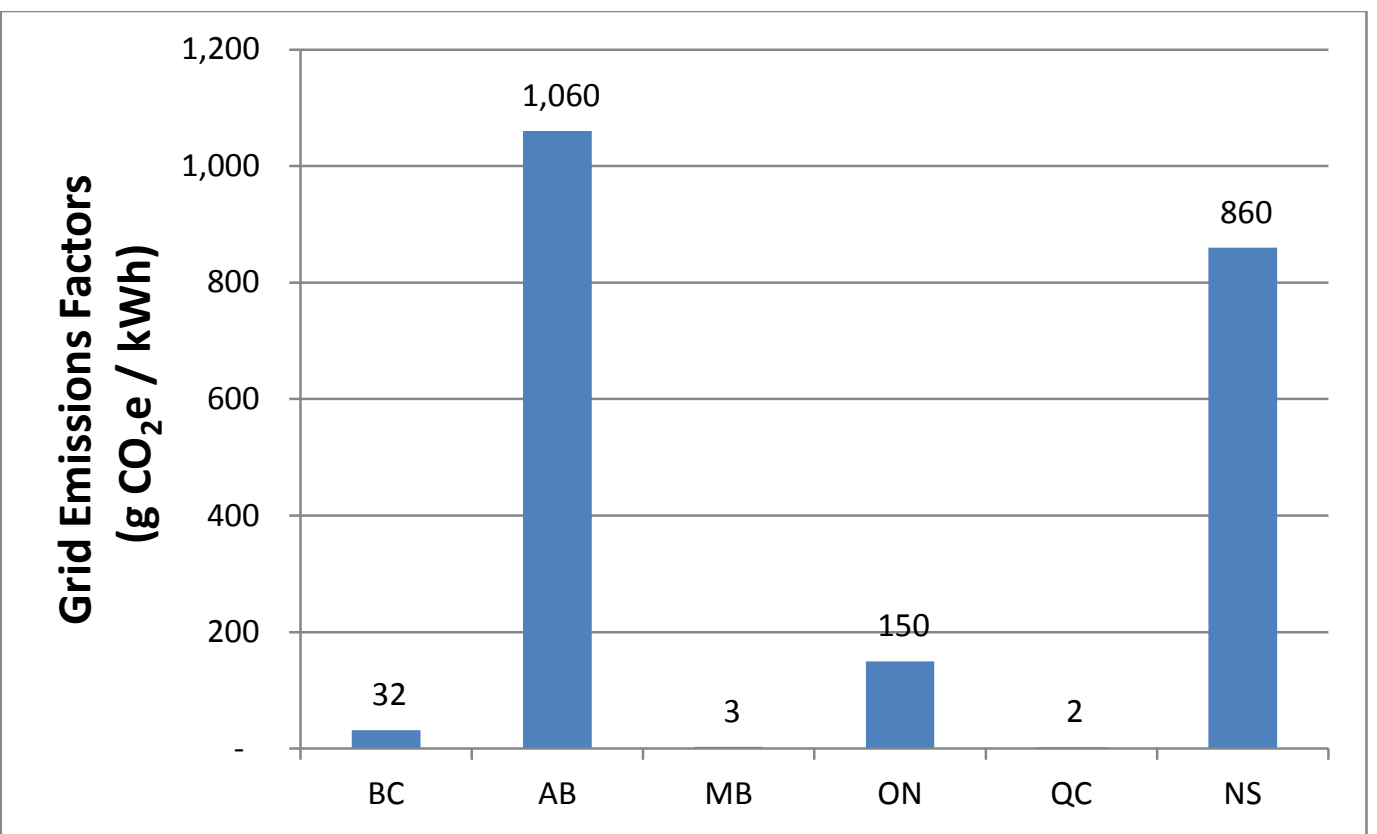

Figure 3: Grid Emissions Factors, including Line Losses and SF6 Emissions ( $\left.\mathrm{g} \mathrm{CO}_{2} \mathrm{e} / \mathrm{kWh}\right)$ (NRCan, 2012)

Energy consumption data for domestic hot water (DHW) is calculated based on occupancy, using 2006 provincial data on occupants by unit type (Statistics Canada 2006) and provincial estimates for DHW by unit type from the Office of Energy Efficiency (2012a) to calculate an average. Average energy demand for DHW is calculated for each building type in each province, but is assumed constant across of all eras of construction.

\section{Results \& Discussion}

\section{Per capita emissions and energy demand from study cities}

Clear variation in per capita GHG emissions from the residential sector across the cities studied is observed in Figures 4 and 5. One of the most important factors is the contribution of electricity consumption; cities with relatively high 2010 provincial electricity grid emission intensities are the highest emitters (Edmonton and Halifax, with grid emission intensities of 1,060 and $860 \mathrm{~g} \mathrm{CO}_{2} \mathrm{e} /$ kWh, with emissions of 4.1 and $5.6 \mathrm{t} \mathrm{CO}_{2} \mathrm{e} / \mathrm{cap}$, respectively). Conversely, electricity in Quebec and Manitoba had the lowest emissions intensities in 2010, at 5 and $2 \mathrm{~g} \mathrm{CO}_{2} \mathrm{e} / \mathrm{kWh}$, respectively. As a result, Montreal and Winnipeg demonstrate the lowest residential per capita

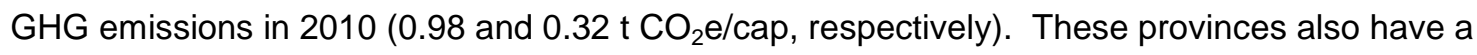


Cite as: Mohareb, E.A., \& Mohareb, A.K., 2014. A comparison of greenhouse gas emissions in the residential sector of major Canadian cities. Canadian Journal of Civil Engineering 41 (4), 285293

high prevalence of electric heat, further improving their emissions relative to provinces reliant on fossil fuel heating. As well, Halifax has higher per capita residential GHG emissions due to the prominence of fuel oil in home heating applications; fuel oil has an emissions factor $\left(\mathrm{t}_{2} \mathrm{e} / \mathrm{GJ}\right)$ that is nearly $40 \%$ greater than natural gas, which is the preferred home heating fuel in many other areas. Direct heating-related GHG emissions were mitigated somewhat in Montreal, Vancouver and Halifax, where appreciable percentages of households rely on wood as a heating fuel (see Supplementary Materials, Table S.8 for details). It should be noted that lifecycle emissions associated with using wood as a fuel source are not negligible, and require replacement of harvested biomass to achieve carbon neutrality (McKechnie et al, 2011). 
Cite as: Mohareb, E.A., \& Mohareb, A.K., 2014. A comparison of greenhouse gas emissions in the residential sector of major Canadian cities. Canadian Journal of Civil Engineering 41 (4), 285293

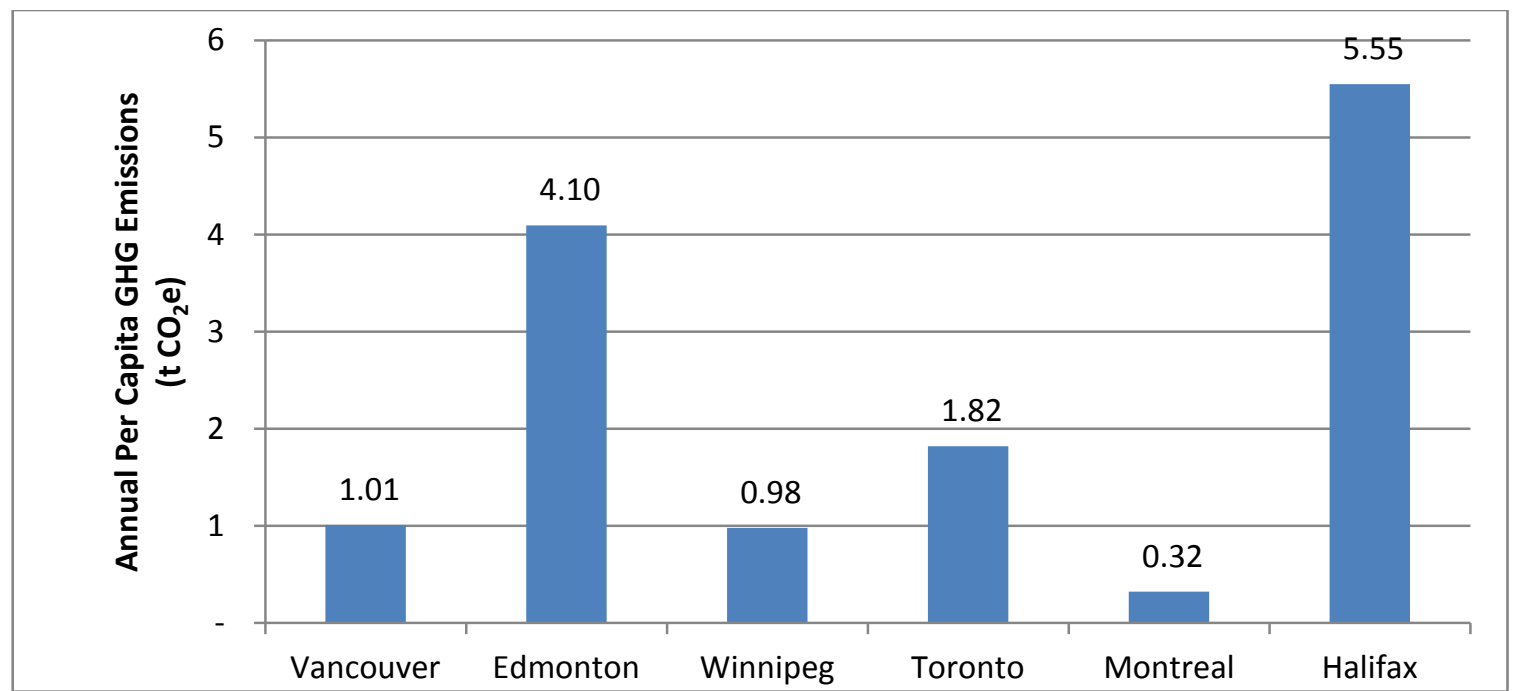

Figure 4: Per Capita Residential Sector Greenhouse Gas Emissions in 2010 Calculated Using the PURGE Model

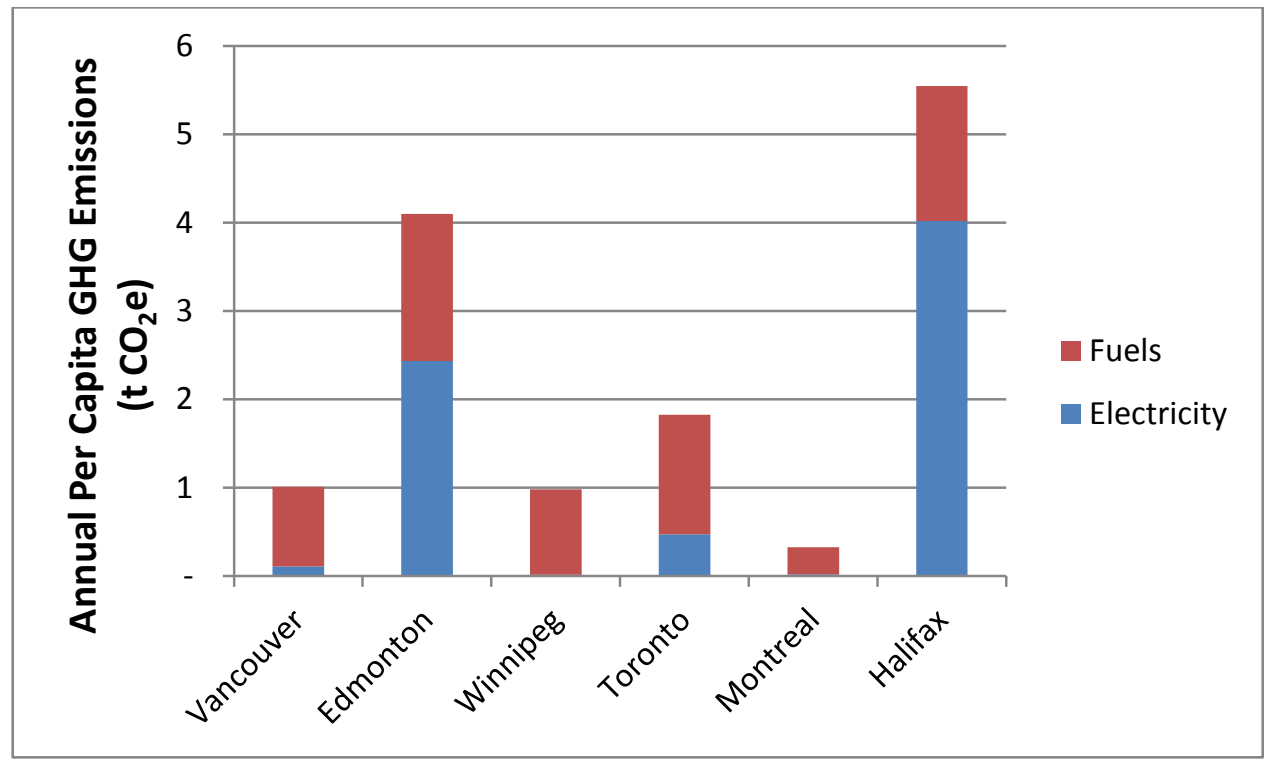

Figure 5: Per Capita Residential Sector Greenhouse Gas Emissions in 2010 Calculated Using the PURGE Model, by Fuel Type

Emissions by end-use can be seen for the different building types in Figure 6. Generally, MURs emit fewer GHG emissions per capita (given their smaller floor space per occupant and lower space conditioning demands per square metre of floor space, with the exception of the city of Edmonton. Edmonton has GHG emissions from MURs that are greater than SFAs and SFDs, 
which is counterintuitive given that energy demands are generally smaller in apartment buildings due to smaller floor area and lower energy demand per unit of floor area. However, in this case, the greater energy demand per capita in MURs is attributable to the lower occupancy observed, especially given the average unit size in the Edmonton CMA. Another item of note in Figure 6 is variation in GHG emissions from appliance/lighting electricity use. For example, when contrasting emissions from these end uses in Toronto and Edmonton, the influence of the carbonintensive Alberta electricity grid is observed through its much greater intensity per capita. However, when examining the same cities' heating GHG emissions (which are both based on natural gas), greater similarity is observed.



Figure 6: Per Capita Residential Sector Greenhouse Gas Emissions in 2010 Calculated Using the PURGE Model, by End Use and Building Type

Figure 7 provides modeled energy consumption per capita in the cities studied here. Vancouver's energy consumption is seen to be lower than other cities (partly due to climate), reflected in lower gross output thermal requirements. Edmonton has a greater reliance on heating fuels to supply 
Cite as: Mohareb, E.A., \& Mohareb, A.K., 2014. A comparison of greenhouse gas emissions in the residential sector of major Canadian cities. Canadian Journal of Civil Engineering 41 (4), 285293

end-use energy requirements, which mitigates per-capita emissions than might otherwise be observed had heating services been supplied through its carbon-intensive electricity grid. Examining per-capita energy demand normalized for HDD (Figure 8), Toronto's homes had higher per-capita energy demand than the other cities examined, while Winnipeg and Edmonton's demand relative to Figure 7 drop from being among the highest to being the lowest. Montreal's milder climate relative to Edmonton and Winnipeg provides it with the advantage of requiring less absolute heating energy, though normalizing these values by HDD shows that Montreal residents require the most energy per capita amongst the three, as seen in Figure 8. Moreover, Montreal relies on heating systems based on a low-carbon electricity grid, which further improves its emissions performance. As stated previously, building age is a concern for residential GHG emissions due in part to differing envelope standards mandated by building codes and changes in construction practices over time. This is demonstrated in the OEE (2012a) database, through modeled gross output thermal requirements that decline for newer construction. As observed in Figure 2, there are a higher proportion of buildings in Montreal and Winnipeg that were built before the 1970 s (50 and 55\%, respectively). Given that the high energy prices of the 1970 s were a key factor in the adoption of more energy efficient residences from that period onward (Perez-Lombard et al 2011), there is an additional energy burden associated with pre-1970s buildings. Cities that have a higher share of newer construction (such as Edmonton, Toronto and Vancouver) will face medium-term difficulties in deep retrofitting in order to achieve substantial GHG emissions reductions; the impacts of rising energy costs will not be felt as severely in newer buildings (Gamtessa 2013), which have locked-in carbon intensive heating systems that are not easily converted to lower carbon options (e.g. replacing natural gas forced-convection systems with geoexchange heat coupled with hydronic systems). 
Cite as: Mohareb, E.A., \& Mohareb, A.K., 2014. A comparison of greenhouse gas emissions in the residential sector of major Canadian cities. Canadian Journal of Civil Engineering 41 (4), 285293

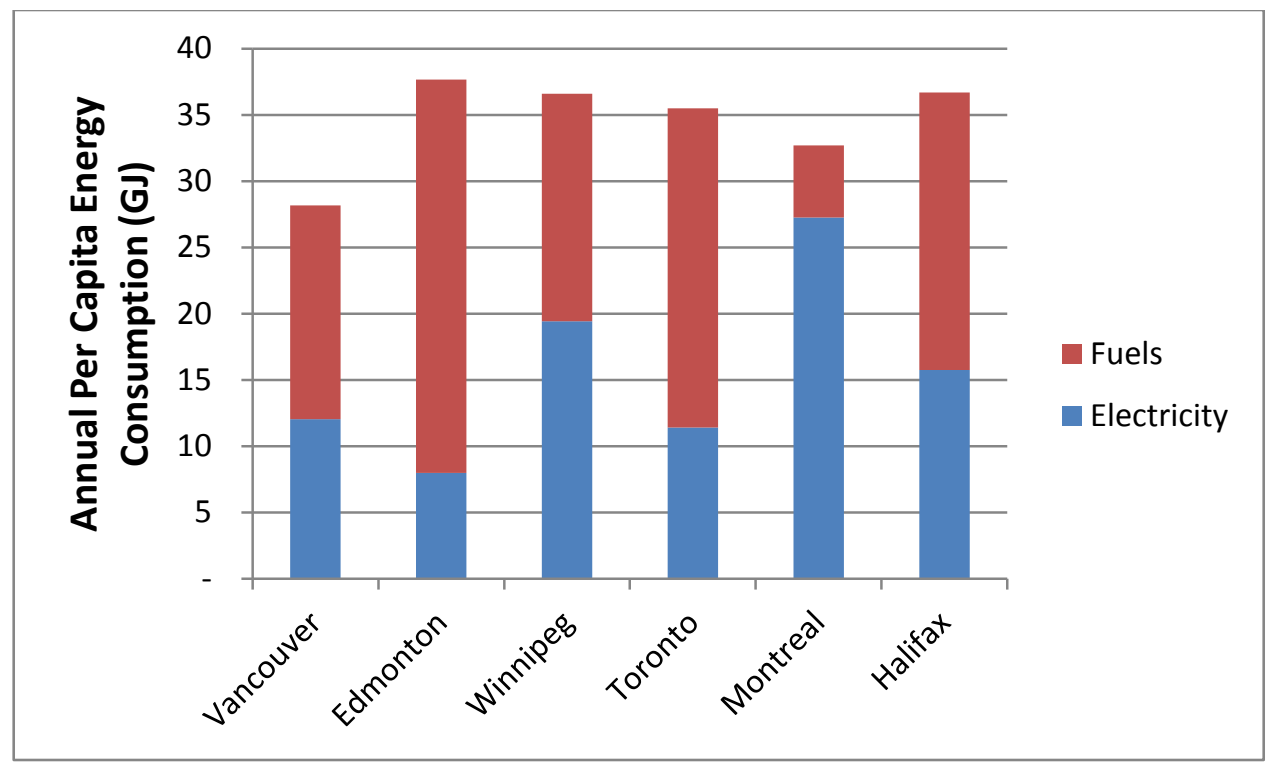

Figure 7: Per Capita Total Energy Consumption Calculated Using the PURGE Model

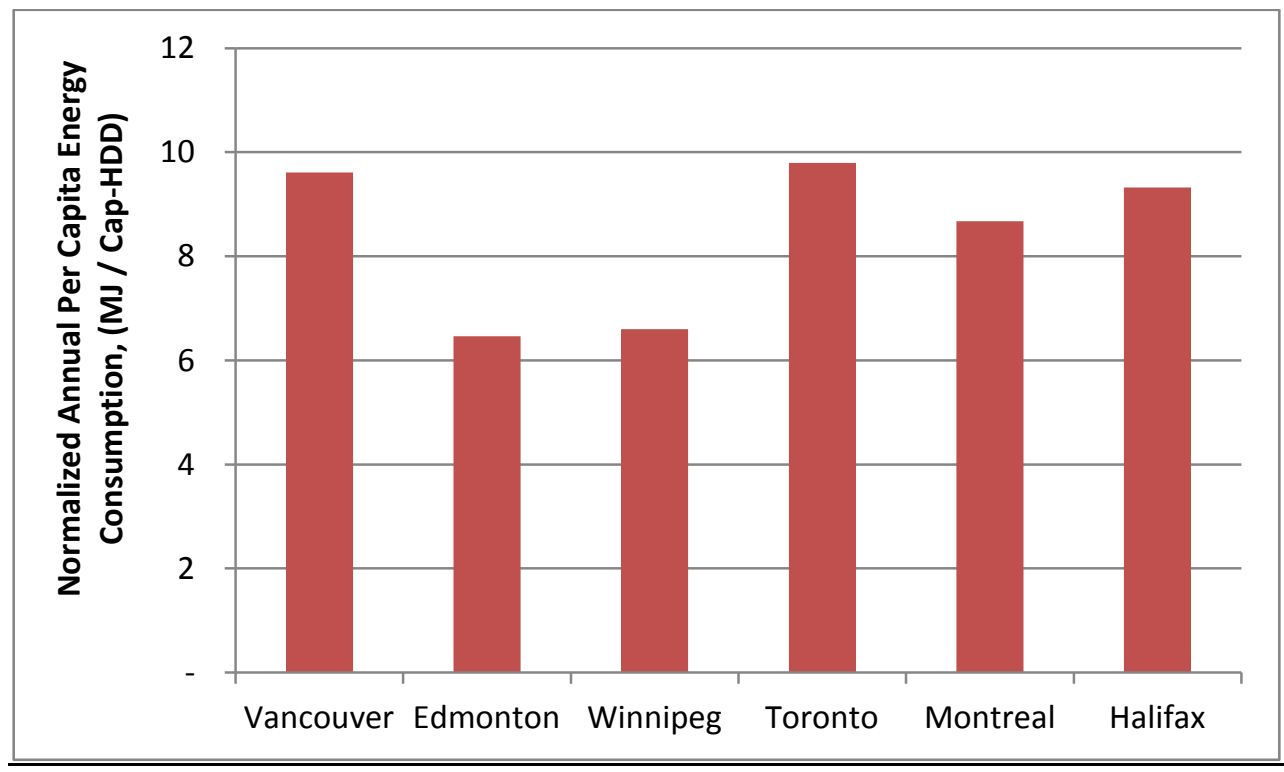

Figure 8: Per Capita Total Energy Consumption Calculated Using the PURGE Model, Normalized for Heating Degree Days (HDD)

Examining GHG emissions from all households from different eras, the implications of a carbon intensive electricity grid are observed once more, with residences in Edmonton and Halifax emitting much more relative to the other cities studied (Figure 9). Another trend that can be observed in nearly all cities is the rise in household emissions in recent years, after a period of decline (particularly evident in Edmonton, Halifax, Toronto and Vancouver). Two factors 
Cite as: Mohareb, E.A., \& Mohareb, A.K., 2014. A comparison of greenhouse gas emissions in the residential sector of major Canadian cities. Canadian Journal of Civil Engineering 41 (4), 285293

contribute to this recent increase - growth in floor space per unit and relative increases in the share of single family dwellings. The increase in floor space suggests consideration of zonal approaches to space conditioning (Dixon et al, 2012). One benefit from the recent focus on building single family dwellings is that there is a potential for geoexchange since horizontal loops may be more practical on the larger land area per housing unit.

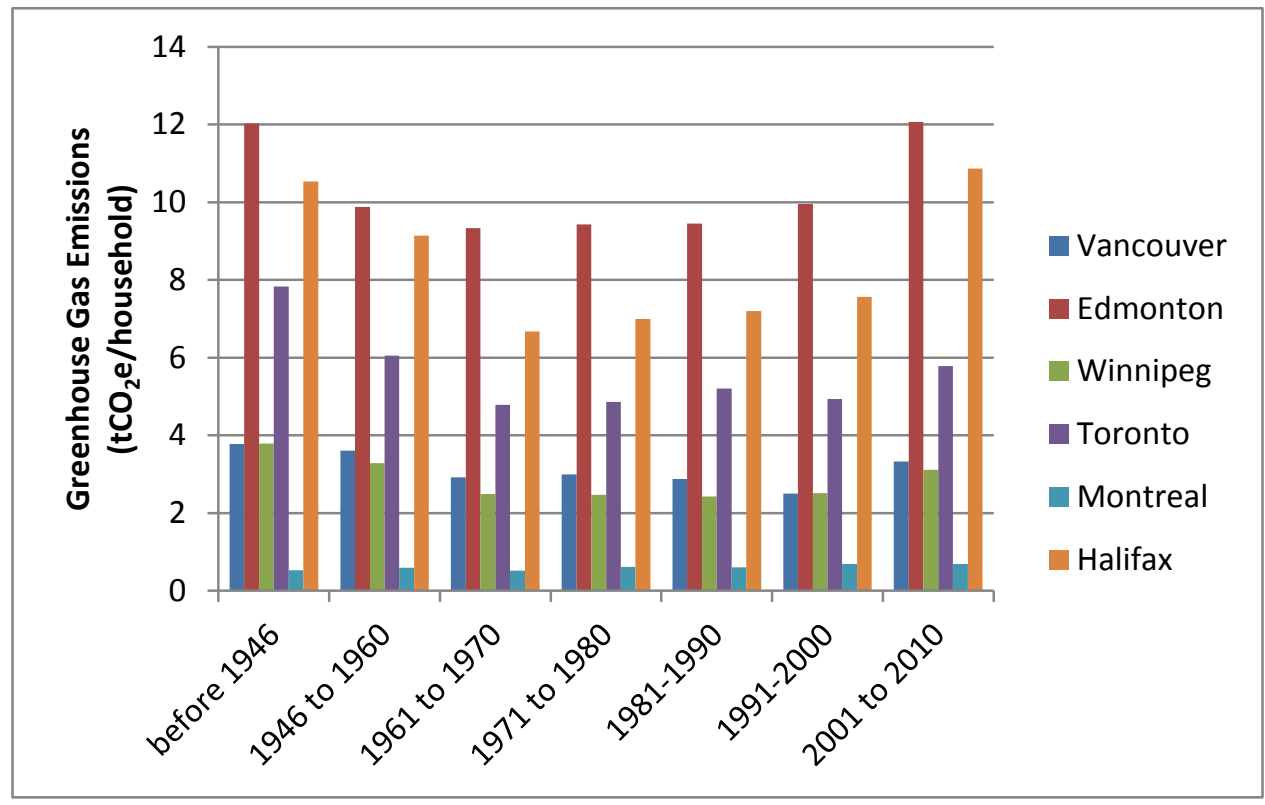

Figure 9: Greenhouse Gas Emissions per Household for Various Eras of Construction Calculated Using the PURGE Model

It's worth also noting that pre-1970's construction houses consume $56 \%$ and $59 \%$ of space heating energy for Montreal and Winnipeg, respectively, which may be less than may first be expected. This lower than expected energy demand from older buildings can also be attributed to an increase in floor area per unit over time; while older buildings are typically less efficient, they also have a smaller floor area to heat in Manitoba and Quebec (OEE 2012a). Additionally, Montreal has built a greater proportion of single family dwellings in recent years, in place of MUR units. This has the result of increased per capita energy demand in buildings built since 1970 .

From a more positive perspective, older buildings were observed to be retrofitted more often than newer buildings during the EnerGuide for Homes national retrofit program (Aydinalp et al 2001; Gamtessa 2013). This could suggest that cities with a greater share of older buildings in their 
Cite as: Mohareb, E.A., \& Mohareb, A.K., 2014. A comparison of greenhouse gas emissions in the residential sector of major Canadian cities. Canadian Journal of Civil Engineering 41 (4), 285293

housing stock may be more successful in incentivizing home-owners to upgrade to more efficient technologies and, potentially, to undertake deep retrofits.

Building types, floor area per unit type/era, and residence occupancy will also have a marked effect in the calculation of GHG emissions. Modeled data presented in OEE (2012a) show MUR units generally demand less thermal energy, followed by SFA and SFD (with an exception to this ranking observed in Edmonton, where SFUAs require less heating per unit area than MURs; see discussion above). As stated previously, the provincial average of floor area by building type generally increases over time (OEE 2012a). While this increases energy demand for conditioned spaces, this increase would generally be overshadowed by decreases in energy demand per unit area. Finally, occupancy per unit type obtained from census microdata (Statistics Canada 2006) has an impact on per capita GHG emissions and energy demand; while SFD/SFAs often have greater total floor area, they also generally have higher occupancies which can produce the result that MUR occupants have higher per capita emissions (as is the case with Edmonton).

\section{Challenges in Achieving an 80\% Reduction in Residential GHG Emissions}

Municipalities require unique, context-specific approaches to reduce GHG emissions from the residential building stock. Quantification of this sector on whole is promoted by the Federation of Canadian Municipalities' Partners for Climate Protection program (FCM 2013). This study provides greater clarity to identify where emissions are most prominent in the Canadian building stock through the examination of six representative cities. The following is a discussion of how the sources of these emissions may be addressed.

There can be split incentives for energy efficiency upgrades in the housing sector between the energy users and those who pay utility costs, particularly in the rental market. In the case where the tenant pays the costs of utilities, the property owner has limited incentive to complete retrofit projects that could reduce energy demand. Additionally, there is evidence that renters use more energy because they are often offered lower efficiency appliances, due to lower capital costs for property owners (Davis 2010). Alternatively, in a case where the landlord pays utility bills, the 
Cite as: Mohareb, E.A., \& Mohareb, A.K., 2014. A comparison of greenhouse gas emissions in the residential sector of major Canadian cities. Canadian Journal of Civil Engineering 41 (4), 285293

occupant has the option to consume energy without consideration of the financial repercussions. One alternative would be to impose a by-law that requires the publishing of rental unit energy consumption data, so that full rental costs are understood and an incentive is created for landlords to address energy demand (Davis and Levine 2012). The same could be done for nonrental building energy labelling at point of sale. Other solutions include high efficiency appliance and energy efficient envelope rebates, city-level residential energy conservation ordinances (where residential sales or major retrofits must be accompanied by energy efficiency improvements), subsidized direct install programs, creative financing options that encourage energy efficiency (e.g. "green" leases, utility on-bill financing, local improvement charges and property-assessed clean energy loans), and increasing general public awareness of the benefits of reducing energy consumption (Williams 2008).

The emergence of consumer electronics and appliances as major energy end-uses must be considered for future municipal plans targeting carbon neutrality, in light of the finding that heating/cooling no longer dominate US residential energy use (USEIA 2011). While provincial averages in appliance ownership were incorporated into the calculations above, consumer electronics (computers, DVD players, TVs, etc.) and other small appliances (microwaves, blenders, etc.) were not. As both the numbers of personal electronic devices per household and housing thermal efficiency increases, the relative contribution of these end-uses to household energy demand will increase. Additionally, energy switching from fuels to electricity (through a conversion towards air-source heat pumps and geoexchange systems) to meet other end-use requirements will alter daily demand profiles, which is especially of concern in jurisdictions where renewable electricity resources do not dominate the baseload and/or peaking electricity supply (Nova Scotia or Alberta), or where electricity supply expansion currently includes fossil sources (such as natural gas-fired generation in Ontario).

Given that $80-90 \%$ reductions in residential GHG emissions are suggested for developed countries such as Canada (IPCC 2007) in order to avoid increasing global average temperatures by more than $2^{\circ} \mathrm{C}$, a combination of occupant behaviour change and adoption of low-carbon 
Cite as: Mohareb, E.A., \& Mohareb, A.K., 2014. A comparison of greenhouse gas emissions in the residential sector of major Canadian cities. Canadian Journal of Civil Engineering 41 (4), 285293

technologies will be necessary. Low-carbon energy sources, high-efficiency systems (e.g. district energy) and the elimination of fossil fuel-based heating are needed in each jurisdiction if Canadian cities are to achieve carbon neutrality. Differing scales of investment will be required in each region to achieve these goals. While short-term policy to promote the switching of heating to electric sources (geoexchange or air-source heat pumps) may result in higher emissions in jurisdictions with carbon-intensive electricity grids, there may be a short-term benefit to their adoption due to the growth of technical expertise, as well as greater public awareness and acceptance. Though the elimination of fossil fuel-based heating energy services within the residential sector will likely require increased electrical grid capacity and overall electricity demand, there is significant potential to meet this increase with low-carbon alternatives in the long-term (i.e. small-scale hydro, wind, solar, geothermal). Leadership for low-carbon electricity strategies must be taken with the ultimate goal of providing a clean grid (which is generally becoming more economically attractive as solar PV and wind prices continue to decline; Hurlbut et al 2013), given the need to drastically reduce GHG emissions in developed nations, and the potential for increases in total residential electricity demand as population and adoption of consumer electronics increase. The importance of behavioural change cannot be overlooked, since even aggressive technology adoption may not produce emission reductions on the scale desired (Mohareb and Kennedy 2013). Reducing space conditioning demand through more sophisticated thermostats and improved energy use feedback technologies represent two ways that GHG reduction can be achieved through behaviour changes (Moon and Han 2011; Granderson et al 2011).

Very aggressive building retrofits must be part of the path to carbon neutrality in the Canadian housing stock. For example, retrofitting activities observed during Canada's recent federal ecoENERGY program did not achieve demand reductions in individual homes on the scale suggested by the IPCC's 2050 targets (80-95\% below 1990 emissions) (Mohareb and Kennedy 2012). Additionally, energy codes for buildings should track best practices in energy efficient building construction. The concept of future-proof buildings needs to be considered in these energy code improvements, where forthcoming low-carbon technologies or behaviour changes 
Cite as: Mohareb, E.A., \& Mohareb, A.K., 2014. A comparison of greenhouse gas emissions in the residential sector of major Canadian cities. Canadian Journal of Civil Engineering 41 (4), 285293

can be implemented in the face of energy pricing uncertainty (Georgiadou et al 2012). Improved integration of the building supply chain, multi-project alliances between design/construction firms (for increased knowledge transfer), and improved consumer understanding of the benefits of energy efficient technologies to strengthen market demand will help to incentivize builders towards greater adoption of high performance buildings and enable sector-wide growth in energy efficient construction and retrofit capacity (Sheffer and Levitt 2010).

The scale of retrofits / reconstruction required to drastically reduce GHG emissions from the building stock necessitates alternative funding schemes to ensure wide-spread adoption of new systems (for a discussion of potential life-cycle costs for single family units, see Dong et al. 2005). Carbon pricing has a valuable role to play in moving Canadians towards a low-carbon building stock (NRTEE 2009), generating revenue from utilities and increasing incentives to reduce energy consumption (including behaviour). For example British Columbia's carbon tax has resulted in a $15 \%$ reduction in petroleum fuel consumption, with new revenues allowing the reduction of other provincial taxes by $\$ 300$ million (Sustainable Prosperity 2012). Revenues from such schemes can be used to subsidize costs to property owners in reducing energy demand through deep retrofits or reconstruction. Residents in cities with high current residential GHG emissions face risks associated with carbon pricing, in addition to risks associated with fossil energy price volatility, with potential impacts on the livability of these cities in the future for lowerincome residents. Innovative provincial and municipal policies (such as Ontario's local improvement charges and Vancouver's HELP program; Ontario Ministry of Municipal Affairs and Housing 2013; City of Vancouver 2013) to finance energy retrofits or renewable energy projects should be leveraged in the short-term to address high project capital costs and reduce these risks.

In summary, in order to achieve absolute emissions reductions on the scale suggested by the IPCC (2007), the Canadian residential sector will require a number of aggressive actions. A preliminary list is provided here, though further research assist in identifying the value of each of these. The preliminary GHG mitigation list includes: 
Cite as: Mohareb, E.A., \& Mohareb, A.K., 2014. A comparison of greenhouse gas emissions in the residential sector of major Canadian cities. Canadian Journal of Civil Engineering 41 (4), 285293

i. switching furnace fuels to low carbon heating systems (e.g. geoexchange);

ii. eliminating fossil fuel electricity generation to facilitate the adoption of established lowcarbon technologies where they are appropriate;

iii. adopting district energy heating systems (especially biomass-based systems);

iv. deep building envelope retrofitting or large-scale reconstruction of the existing building stock;

v. behavioural change in energy use (especially targeting lower space conditioning energy demand);

Additionally, the following measures would also deter the growth of future emissions:

vi. a greater proportion of MURs in the housing stock (which can also address transportation energy demand when combined with appropriate urban planning policy);

vii. rapid revision of the building code to drastically reduce energy consumption levels (including provisions such as mandatory heat recovery ventilators, reductions in air leakage, southward orientation of buildings, compulsory solar thermal/PV-readiness and higher insulation requirements), as is being targeted in the European Union and the State of California (European Parliament, 2010; California Public Utilities Commission, 2008); and

viii. addressing the split incentive for energy efficiency between property owners and renters.

\section{Limitations to the PURGE Model}

There are limitations to the data applied in this study that should be discussed, as impacts will be observed in the results provided above. First, much of the energy end-use data is derived from the OEE (2012a) database, developed through their end-use model, not from actual end-use data. Second, appliance stocks, floor area and hot water consumption are taken from provincial estimates, and may not accurately represent differences observed in urban centres. Finally, occupancy per unit type (MUR, SFA, and SFD) is assumed to be constant, due to the absence of 
Cite as: Mohareb, E.A., \& Mohareb, A.K., 2014. A comparison of greenhouse gas emissions in the residential sector of major Canadian cities. Canadian Journal of Civil Engineering 41 (4), 285293

data that might indicate otherwise. It is possible that more spacious dwellings also have higher occupancies, which would result in per capita emissions being shifted downwards slightly.

\section{Conclusions}

The six cities assessed in this article face different challenges in reducing GHG emissions; it is important to note the importance of type of secondary energy involved in residential systems (hydro-based electric versus natural gas versus fuel oil). Occupancy, building type and floor area per unit are also seen to influence per capita emissions. Ages of buildings also impact current and future GHG emissions, through the quality of building envelopes and the economics of retrofits. If Canadian cities are going to significantly reduce GHG emissions, barriers to improving the energy efficiency of the building stock (such as split incentives, unattractive financing options and unambitious energy codes) must be addressed in an aggressive fashion in the years towards 2050.

\section{References}

Aydinalp, M., Ferguson, A., Fung, A., and Ugursal, I.V., 2001. EnerGuide for Houses Database Analysis. Canadian Residential Energy End-Use Data and Analysis Centre (CREEDAC) Report to Natural Canada, April 3, 2001.

Bettencourt, L.M.A., Lobo, J., Helbing, D., Kuhnert, C. and West, G.B., 2007. Growth, innovation scaling and the pace of life in cities. Proceedings of the National Academy of Sciences, 104(17), 7301-7306.

California Public Utilities Commission, 2008. California Long-Term Energy Efficiency Strategic Plan. [Online] Available at:

http://www.cpuc.ca.gov/NR/rdonlyres/D4321448-208C-48F9-9F62-

1BBB14A8D717/0/EEStrategicPlan.pdf, Accessed February 27, 2014 
Cite as: Mohareb, E.A., \& Mohareb, A.K., 2014. A comparison of greenhouse gas emissions in the residential sector of major Canadian cities. Canadian Journal of Civil Engineering 41 (4), 285293

City of Vancouver, 2013. Home Energy Loan Program. [Online] Available HTTP: https://www.vancity.com/Loans/TypesOfLoans/HomeEnergy/, Accessed April 23, 2013

City of Winnipeg, 2007. Population, Housing and Economic Forecasts for Winnipeg CMA and the City of Winnipeg. Prepared by the City of Winnipeg CAO Secretariat. [Online] Available HTTP: http://www.winnipeg.ca/cao/pdfs/population forecast.pdf, Accessed March 18, 2013.

Civic Action, 2011. The Living City Report Card 2011. [Online] Available HTTP: http://www.thelivingcity.org/lcrc/LivingCityReportCard web r1.pdf. Accessed July 28, 2013.

Climate Action Secretariat 2013. Metro Vancouver Regional District - 2010 Community Energy and Emissions Inventory. [Online] Available HTTP: http://www.env.gov.bc.ca/cas/mitigation/ceei/RegionalDistricts/MetroVancouver/ceei 2010 metro-vancouver regional district.pdf. Accessed December 29, 2013.

Davis L.W., 2010. Evaluating the Slow Adoption of Energy Efficient Investments: Are Renters Less Likely to Have Energy Efficient Appliances? Working Paper from the Energy Institute at Haas. [Online] Available HTTP: http://bit.ly/10gXmcQ. Accessed March 24, 2013.

Davis L.W., and Levine, D.I., 2012. Renting Inefficiency. [Online] Available HTTP: http://energyathaas.wordpress.com/2012/11/26/renting-inefficiency/. Accessed April 10, 2013.

Dong B., Kennedy C., and Pressnail K., 2005. Comparing Life-Cycle Implications of Building Retrofit and Replacement Options. Canadian Journal of Civil Engineering, 32(6), 1051-1063

Doran, P. T. and M. K. Zimmerman, 2009. Examining the scientific consensus on climate change. Eos 90(3): 22-23.

Environment Canada, 2012. National Inventory Report 1990-2010: Greenhouse Gas Sources and Sinks in Canada. [Online] Available HTTP: http://www.ec.gc.cal. Accessed March 13, 2013. 
Cite as: Mohareb, E.A., \& Mohareb, A.K., 2014. A comparison of greenhouse gas emissions in the residential sector of major Canadian cities. Canadian Journal of Civil Engineering 41 (4), 285293

European Parliament, 2010. Directive 2010/31/EU. [Online] Available HTTP: http://eurlex.europa.eu/LexUriServ/LexUriServ.do?uri=OJ:L:2010:153:0013:0035:EN:PDF， Accessed February 27, 2014.

Federation of Canadian Municipalities, 2013. Federation of Canadian Municipalities - Partners for Climate Protection. [Online] Available HTTP: http://www.fcm.ca/, Accessed August 9, 2013

Gamtessa S.F., 2013. An Explanation of Residential Energy-Efficiency Retrofit Behaviour in Canada. Energy and Buildings, 57, 155-164.

Georgiadou, M.C., Hacking, T., and Guthrie, P., 2012. A Conceptual Framework for FutureProofing the Energy Performance of Buildings. Energy Policy, 47, 145-155.

Granderson, J., Piette, M.A., and Ghatikar, G., 2011. Building Energy Information Systems User Case Studies. Energy Efficiency, 4, 17-30.

IEA, 2008. World Energy Outlook. International Energy Agency.

IPCC, 2007. Climate Change 2007: Mitigation. Cambridge University Press, Cambridge, United Kingdom and New York, NY, USA. See Chapter 13, Box 13.7.

Kesik, T, 2011. The Glass Condo Conundrum. [Online] Available HTTP: http://www.cbc.ca/toronto/features/condos/pdf/condo conundrum.pdf, Accessed March 20, 2013.

Kikuchi, E., Bristow, D. and Kennedy, C.A. 2009. Evaluation of region-specific residential energy systems for GHG reductions: Case studies from Canadian cities. Energy Policy, 37, 1257-1266.

Mansell, R.L. and Schlenker, R., 2006. Energy and the Alberta Economy - Past and Future Impacts and Implications. Paper No.1 of the Alberta Energy Futures Project, ISEEE, University of Calgary. [Online] Available HTTP: http://bit.ly/11dAQOH, Accessed March 19, 2013. 
Cite as: Mohareb, E.A., \& Mohareb, A.K., 2014. A comparison of greenhouse gas emissions in the residential sector of major Canadian cities. Canadian Journal of Civil Engineering 41 (4), 285293

McKechnie J., Colomb, S., Chen, J., Mabee, W., and Maclean, H.L., 2011. Forest Bioenergy or Forest Carbon? Assessing Trade-Offs in Greenhouse Gas Mitigation with Wood-Based Biofuels. Environmental Science and Technology,45, 789-795.

Mohareb, E.A. and Kennedy, C.A, 2012. Greenhouse Gas Emission Scenario Modeling for Cities using the PURGE Model. Journal of Industrial Ecology, 16(6), 875-888.

Mohareb, E.A. and Kennedy, C.A., 2014. Scenarios of Technology Adoption towards LowCarbon Cities. Energy Policy. 66: $685-693$.

Moon, J.W., and Han, S.H., 2011. Thermostat Strategies Impacts on Energy Consumption in Residential Buildings. Energy and Buildings, 43, 338-346.

Hurlbut, D.J., McLaren J., Gelman R., 2013. Beyond Renewable Portfolio Standards - An Assessment of Regional Supply and Demand Conditions Affecting the Future of Renewable Energy in the West. National Renewable Energy Research Lab Report NREL/TP-6A20-57830 August 2013.

National Research Council, 2010. Updating the Model National Energy Code for Buildings. [Online] Available HTTP: http://www.nrc-cnrc.gc.ca/, Accessed April 10, 2013.

National Round Table on Environment and the Economy, 2009. Achieving 2050: a Carbon Pricing Policy for Canada. ISBN 978-0-662-06538-8

Natural Resources Canada 2012. Residential End-Use Model, Ottawa, 2012.

Nova Scotia Department of Energy, 2010. Renewable Action Plan. [Online] Available HTTP: http://www.gov.ns.ca/energy/resources/EM/renewable/renewable-electricity-plan.pdf. Accessed April 23, 2013.

Office of Energy Efficiency, 2010. 2007 Survey of Household Energy Use - Data Tables. [Online] Available HTTP: http://oee.nrcan.gc.ca/, Accessed April 9, 2013. 
Cite as: Mohareb, E.A., \& Mohareb, A.K., 2014. A comparison of greenhouse gas emissions in the residential sector of major Canadian cities. Canadian Journal of Civil Engineering 41 (4), 285293

Office of Energy Efficiency, 2012a. Comprehensive Energy Use Database, 1990-2010. [Online] Available HTTP: http://oee.nrcan.gc.ca, Accessed March 14, 2013.

Office of Energy Efficiency 2012b. Energy Consumption of Major Household Appliances Trends for 1990-2010. [Online] Available HTTP: http://oee.nrcan.gc.ca/, Accessed April 9, 2013.

Ontario Ministry of Municipal Affairs and Housing, 2013. Local Improvement Charges. [Online] Available HTTP: http://bit.ly/17GN1XT, Accessed April 10, 2013.

Perez-Lombard, L., Ortiz, J., Coronel, J.F., and Maestre, I.R., 2011. A Review of HVAC Systems Requirements in Building Energy Regulations. Energy and Buildings, 43(2-3), 255-268

Dixon, E., Richman, R. C. and Pressnail, K. D., 2012. Nested Thermal Envelope Design construction: Achieving significant reductions in heating energy use, Energy and Buildings, $201254215-224$.

Sheffer, D.A., and Levitt, R.E., 2010. The Diffusion of Energy Saving Technologies in the Building Sector: Structural Barriers and Possible Solutions. Working Paper \#57. Collaboratory for Research on Global Projects. [Online] Available HTTP: http://stanford.io/173whZG, Accessed April 11, 2013

Statistics Canada, 2010. Canada's Population Becoming More Urban. [Online] Available HTTP: http://www.statscan.gc.ca, Accessed October 22, 2012.

Statistics Canada, 2005. Population Growth and Components, 1851-2001 Censuses. [Online] Available HTTP, http://bit.ly/173wbBg. Accessed March 1, 2013.

Statistics Canada, 2006. Census of Population, Statistics Canada catalogue no. 97-559XCB2006024

Statistics Canada, 2011. Census of Population, Statistics Canada catalogue no. 97-559XCB2006024 
Cite as: Mohareb, E.A., \& Mohareb, A.K., 2014. A comparison of greenhouse gas emissions in the residential sector of major Canadian cities. Canadian Journal of Civil Engineering 41 (4), 285293

Statistics Canada, 2012. Census Profiles, 2011 Census. Statistics Canada catalogue no. 98316-XWE. Ottawa. Released October 24, 2012.

Sustainable Prosperity, 2012. British Columbia's Carbon Tax Shift - The First Four Years. [Online] Available HTTP: http://www.sustainableprosperity.ca/dl872\&display, Accessed April 23, 2013.

United Nations Department of Economic and Social Affairs, 2013. World Urbanization Prospects - the 2011 Revision. [Online] Available HTTP: http://esa.un.org/unup/, Accessed December 21,2013

United States Energy Information Administration, 2011. Share of Household Energy Used by Appliances and Consumer Electronics Increases in US Homes. [Online] Available HTTP: http://1.usa.gov/11gBGYb, Accessed March13, 2013

Williams, B., 2008. Overcoming Barriers to Energy Efficiency for Rental Housing. Master in City Planning Thesis, Massachusetts Institute of Technology. [Online] Available HTTP: http://bit.ly/173vWpN, Accessed April 18, 2013.

Wilson, J., Spinney, J., Millward, H., Scott, D., Hayden, A., and Tyedmers, P., 2013a. Blame the exurbs, not the suburbs: Exploring the distribution of greenhouse gas emissions within a city region. Energy Policy, 62(1329-1335).

Wilson, J., Tyedmers, P., and Grant, J., 2013b. Measuring environmental impact at the neighbourhood level. Journal of Environmental Planning and Management, 56, 42 - 60. 